\title{
Digital Marketing of Serpong Urbantown Apartments to Increase Brand Awareness and Customer Satisfaction
}

\author{
Kevin Lye ${ }^{1}$, Rudi Santoso ${ }^{*}$ \\ 1,2Faculty of Economics and Business, Dinamika University \\ e-mail: rudis@dinamika.ac.id ${ }^{2}$ \\ *Corresponding Author: E-mail: rudis@dinamika.ac.id
}

\begin{tabular}{|c|c|}
\hline ARTICLE INFO & ABSTRACT \\
\hline $\begin{array}{lr}\text { Keywords: } & \text { Customer } \\
\text { Satisfaction, } & \text { Digital } \\
\text { Marketing, Social Media }\end{array}$ & $\begin{array}{l}\text { This research focuses on the efforts of Apartment Urbantown } \\
\text { Serpong to increase Brand Awareness. The strategy offered in this } \\
\text { research is marketing communication using digital marketing. } \\
\text { The use of social media in marketing communications in this } \\
\text { study aims to provide a different perspective or point of view } \\
\text { from the activities of the digital marketing process. This study } \\
\text { also examines digital marketing strategies to increase Brand } \\
\text { Awareness Apartment Urban town Serpong. This study uses a } \\
\text { qualitative descriptive method with a literature review approach. } \\
\text { The results show that digital marketing strategies are proven to } \\
\text { be able to increase brand awareness. The indicator used in this } \\
\text { study is the impact or response from research sources to identify } \\
\text { the Serpong Urban town Apartment brand. }\end{array}$ \\
\hline
\end{tabular}

\section{Introduction}

Business in the digital era is disrupted both in terms of competition, sales behavior, and buying behavior. Everything has shifted rapidly, especially business competition. This cannot be separated from the support of very open information. Moreover, social media provides support for the rapid dissemination of information. Research [1] reveals that the use of social media for marketing communications is increasingly common. In addition to increasing customer awareness of the brand, this strategy is considered low-cost. Digital marketing activities using social media have become a trend in millennial years. This is inseparable from the digital trend and industry 4.0 which is increasingly plural. Research [2], [3] reveals that brand awareness can be increased through the use of social media. Social media began to be used in 2002 although it is still limited to friendship. Friendster is a social media for friendship created by Jonathan Abrams, a British programmer, who became the forerunner of social media in the millennial era. Two years later, Mark Zuckerberg introduced FaceBook (FB) to the world which later became the number one social media until 10 years later.

Digital-based communication is a trend that cannot be separated from the millennial lifestyle. High speed of information, reach, efficiency, accuracy are the added value of the communication model. It is used by companies, organizations, social groups, and individuals to interact with each other in exchanging information. Further developments, the company uses this digital communication model to speed up the process of transferring information to customers. Then developed a digital-based 
marketing model. The speed of information transfer from the company to the consumer can accelerate brand awareness for customers. Research conducted [4]-[6] found that brand awareness that is built in the minds of customers will affect purchase intentions. Research conducted by [7] also shows that marketing communication in social media plays a very important role in shaping the brand awareness of a company, especially for social media users. This is in line with research [8] which reveals that integrated marketing communications can have a good effect on brand equity. The process of building brand awareness can be started by building awareness of the company's products. Awareness of this company's products will have an impact on customer satisfaction which ultimately forms customer loyalty to the company.

The Urban Town Apartment is an apartment complex located in downtown Serpong. This apartment targets the upper middle class with a comfortable residential concept. This residence is relatively new when compared to other apartment dwellings. This apartment has the opportunity to become a residential complex that can win the hearts of customers. However, this apartment brand has received less attention from consumers. Initial data obtained from interviews with customers, residents, prospective residents stated that the residential concept was quite good but lacked promotion so that this brand or brand was not known or not yet known by the public as an alternative residential choice.

Brand awareness is basically a brand strength that is in the minds of customers. This can be assessed by measuring the ability of consumers to provide identification of the brand in various variations and conditions. Brand management or brand according to [9] must be done properly by the company. Because it will cost a lot to do marketing if big brands are competing. This is inseparable from the company's efforts to create brand awareness itself. A study conducted [10] found that the influence of brand awareness can be increased by using digital marketing.

Another opinion about brand awareness or better known as Brand Awareness is the ability possessed by customers (general public) to identify a brand, product or service. This brand awareness raising activity needs to be carried out by the company. This is because consumers will buy products or services that are already known to them. Research [11] confirms that brands that are already known by the public will be purchased more than other brands that are not yet known. Consumers have a tendency to buy a brand that already has a previous reputation and is known by the wider community.

One of the big jobs of the company is to build awareness of the brand itself. Companies gain a good brand reputation is not built in a short time. They take a long time to implant in the minds of customers that their brand is exactly what the customer needs. So that brand awareness will be formed by itself. The study conducted [12] proves that the brand awareness that the company builds within a certain time has increased sales intention. This is also inseparable from the behavior of consumers who are always looking for or buying products or services that already have a good reputation.

Meanwhile, research conducted [13] states that brand awareness, brand reputation, and brand associations incorporated in brand equity have an impact on 
purchase intensity. This proves that brand awareness as part of brand assets (brand equity) provides a significant role or influence on increasing sales.

Several things can be done to build brand awareness. The study [14] states that there are at least 5 (five) activities that can be done to build brand awareness. The five things are: 1) creating a product or company logo; 2) use social networks and influencers; 3) participate in performances or events; 4) have a website. The five processes or activities become a single entity that cannot stand alone. That is, if you want to increase brand awareness in customers, then these five things must be done. Some of the points above have indeed become a trend in the past. But then it became too mainstream, such as point 5 having a website. In the current condition, the activity of building brand awareness is not only having a website, but has progressed to point 2, namely using social networks and influencers.

A well-built brand awareness always has a good reputation effect on the brand. The study conducted [15] states that brand awareness, brand trust, and superior products have an influence on the purchase intention of luxury goods. This proves that brand awareness is very important to be considered by companies.

\section{Research Methods}

The literature review is a comprehensive review of previous research. This study aims to develop information that has been previously researched. This research is different from the type of academic research. Academic research will develop new arguments in which literature review is used as the fundamental basis of research. Meanwhile, this research will summarize and synthesize arguments and ideas from previous research without adding new contributions. Several stages were carried out in this research, namely: choosing a topic to be reviewed; obtain supporting journal references; make analysis and synthesis of literature.

\section{Result and Discussion}

\section{a. Digital Marketing Strategy}

Digital Marketing is a strategic trend carried out by companies today. Marketing science in the general sense that was taught in schools a few years ago may no longer be applicable to today's conditions. The current condition is an anomalous condition where customer behavior has changed. This change in behavior is related to the buying decision process and the way to transact. The study [16] underlined that changes in purchasing behavior were affected by the pandemic. Consumers make more purchases online than offline. This change in buying behavior is clearly more profitable for both parties, namely the seller and the buyer. Research [17] explains that online sales have become a necessity since the last 5 years.

Online sales are considered the most rational solution during a pandemic. This is confirmed by [18] who found the phenomenon of online sales to be one of the efforts to increase revenue. These online sales activities also change the seller's marketing strategy. The trend of selling through digital also affects the increase in digital marketing activities. This is also confirmed by [19] that digital marketing activities are much more effective when compared to conventional methods. 


\section{b. Social Media and Marketing Communication}

Social media is one of the tools to carry out a marketing strategy. Besides being used as a marketing tool, social media is also used as a communication medium. The company will communicate the products or services offered through social media. Social media has become a marketing communication tool in the digital era. Research conducted by [20] found that marketing communications have changed from conventional to digital. Some people and companies use social media to promote their products. Social media has become a tool for promoting goods and services.

Market participants are helped by social media to communicate with fellow sellers, customers, and potential customers. Social media has given an identity to a brand to be spread through social media in an easy way. Social media is also able to provide very effective communication to build brand awareness. Studies conducted by [21] Emphasizes that social media and marketing communications are one unit. In other words, marketing communication in the digital era cannot be separated from social media.

\section{c. Brand Awareness and Customer Satisfaction}

Brands that are well recognized by customers will be bought more than those that are not known. This relates to brand awareness by customers. Customers will buy a product that is well known. Customers who are able to identify the product well will trust the product more than other products they are not familiar with. Research conducted [22] found that products that have a good reputation are bought more than products that are not known. Customers will also be more loyal to products that already have a good reputation. Customers who make repeated purchases of the same product are a manifestation of customer satisfaction.

Research on customer satisfaction has also been carried out by [23] Which underlines that customer satisfaction is not only measured by products that have met the expectations of customer needs. Furthermore, a product or service will provide customer satisfaction if the product has a good reputation. Such a good reputation must be built through brand awareness. This is confirmed by [24] that customers will have more confidence in brands that have provided benefits and customer expectations.

\section{Conclusion}

Digital marketing has become a necessity in marketing communications. Several studies that are reviewed in this research prove that digital marketing is proven to increase brand awareness. Brand awareness has helped customers to repurchase a product. It also shows the degree of customer satisfaction. In other words, if the company wants to increase customer satisfaction, it can start by conducting marketing communications using social (digital) media.

\section{References}

[1] G. Octavia and W. P. Sari, "Bentuk Komunikasi Pemasaran Digital ST22 Consulting," Prologia, vol. 2, no. 2, pp. 339-346, 2018. 
[2] K. Melati and F. Febianty, "The Effect of Social Media on The Brand Awareness at Hotels in Kuta Area," J. Bus. Hosp. Tour., vol. 2, no. 1, p. 458, 2016, doi: 10.22334/jbhost.v2i1.80.

[3] S. B. Priatni, T. Hutriana, and E. N. Hindarwati, "Pengaruh Social Media Marketing terhadap Purchase Intention dengan Brand Awareness sebagai Variable Intervening pada Martha Tilaar Salon Day Spa," J. Ekon. Manaj. dan Perbank. (Journal Econ. Manag. Banking), vol. 5, no. 3, p. 145, 2020, doi: 10.35384/jemp.v5i3.165.

[4] S. R. Nikhashemi, L. Paim, S. Osman, and S. Sidin, "The Significant Role of Customer Brand Identification towards Brand Loyalty Development: An Empirical Study among Malaysian Hypermarkets Customer," Procedia - Soc. Behav. Sci., vol. 207, pp. 182-188, 2015, doi: 10.1016/j.sbspro.2015.10.086.

[5] B. Ranjbarian, A. Sanayei, M. R. Kaboli, and A. Hadadian, "An Analysis of Brand Image, Perceived Quality, Customer Satisfaction and Re-purchase Intention in Iranian Department Stores," Int. J. Bus. Manag., vol. 7, no. 6, Mar. 2012, doi: 10.5539/ijbm.v7n6p40.

[6] M. I. Tariq, M. Rafay Nawaz, M. M. Nawaz, and H. A. Butt, "Customer Perceptions about Branding and Purchase Intention: A Study of FMCG in an Emerging Market," J. Basic. Appl. Sci. Res, vol. 3, no. 2, pp. 340-347, 2013.

[7] R. Tarigan and H. B. Tritama, "The Effect of Social Media to the Brand Awareness of A Product of A Company," CommIT (Communication Inf. Technol. J., vol. 10, no. 1, p. 9, 2016, doi: 10.21512/commit.v10i1.904.

[8] N. P. Kartikasari, "Pengaruh Komunikasi Pemasaran Terpadu Terhadap Ekuitas Merek.," Interak. J. Ilmu Komun., vol. 3, no. 2, pp. 162-167, 2014.

[9] G. Kotler, Philip; Armstrong, Principle Of Marketing 15th edition. New Jersey: Pearson Prentice Hall, 2017.

[10] H. Fitrianna and D. Aurinawati, "Pengaruh Digital Marketing Pada Peningkatan Brand Awareness Dan Brand Image Terhadap Keputusan Pembelian Produk Cokelat Monggo di Yogyakarta," INOBIS J. Inov. Bisnis dan Manaj. Indones., vol. 3, no. 3, pp. 409-418, 2020, doi: 10.31842/jurnalinobis.v3i3.147.

[11] G. B. Ilyas, S. Rahmi, H. Tamsah, A. R. Munir, and A. H. P. K. Putra, "Reflective model of brand awareness on repurchase intention and customer satisfaction," J. Asian Financ. Econ. Bus., vol. 7, no. 9, pp. 427-438, 2020, doi: 10.13106/JAFEB.2020.VOL7.NO9.427.

[12] M. S. Rahman, M. A. Hossain, M. T. Hoque, M. R. I. Rushan, and M. I. Rahman, "Millennials' purchasing behavior toward fashion clothing brands: influence of brand awareness and brand schematicity," J. Fash. Mark. Manag., vol. 25, no. 1, 2021, doi: 10.1108/JFMM-07-2019-0137.

[13] R. Santoso, M. S. Erstiawan, and A. Y. Kusworo, "Inovasi Produk, Kreatifitas Iklan Dan Brand Trust Mendorong Keputusan Pembelian," J. Nusant. Apl. Manaj. Bisnis, vol. 5, no. 2, pp. 133-145, Oct. 2020, doi: 10.29407/nusamba.v5i2.14369.

[14] S. Fraccastoro, M. Gabrielsson, and E. B. Pullins, "The integrated use of social media, digital, and traditional communication tools in the $\mathrm{B} 2 \mathrm{~B}$ sales process of 
international SMEs," Int. Bus. Rev., no. November, p. 101776, 2020, doi: 10.1016/j.ibusrev.2020.101776.

[15] B. S, V. A, and G. N, "The impact of social media on business growth and performance in India," J. Manag. Sci., vol. 9, no. 4, pp. 190-194, 2019, doi: 10.26524/jms.2019.22.

[16] R. Santoso, "Review of Digital Marketing \& Business Sustainability of ECommerce During Pandemic Covid19 In Indonesia," J. Ilmu Ekon. Terap., vol. 5, no. 2, pp. 36-48, 2020.

[17] S. Miftah, M. Heru, and S. Riyadi, "Implementasi E-Commerce Sebagai Media Penjualan Online (Studi Kasus Pada Toko Pastbrik Kota Malang)," 2015.

[18] A. Susanto, C. A. Sari, D. R. I. Moses, E. H. Rachmawanto, and I. U. W. Mulyono, "Implementasi Facebook Marketplace untuk Produk UMKM sebagai Upaya Peningkatan Pemasaran dan Penjualan Online," Abdimasku J. Pengabdi. Masy., vol. 3, no. 1, p. 42, 2020, doi: 10.33633/ja.v3i1.64.

[19] V. A. Handini and W. Choiriyati, "Digitalisasi UMKM Sebagai Hasil Inovasi dalam Komunikasi Pemasaran Sahabat UMKM Selama Pandemi Covid-19," J. Ris. Komun.

[20] S. Samsiana et al., "Pemanfaatan Media Sosial dan Ecommerce Sebagai Media Pemasaran Dalam Mendukung Peluang Usaha Mandiri Pada Masa Pandemi Covid 19," J. Sains Teknol. dalam Pemberdaya. Masy., vol. 1, no. 1, pp. 51-62, 2020, doi: 10.31599/jstpm.v1i1.255.

[21] B. P. Kushwaha, R. K. Singh, N. Varghese, and V. N. Singh, “Integrating social media and digital media as new elements of integrated marketing communication for creating," J. Content, Community Commun., vol. 10, no. 6, pp. 52-64, 2020, doi: 10.31620/JCCC.06.20/05.

[22] A. A. Barreda, A. Bilgihan, K. Nusair, and F. Okumus, "Generating brand awareness in Online Social Networks," Comput. Human Behav., vol. 50, 2015, doi: 10.1016/j.chb.2015.03.023.

[23] J. Lahap, N. S. Ramli, N. M. Said, S. M. Radzi, and R. A. Zain, “A Study of Brand Image towards Customer's Satisfaction in the Malaysian Hotel Industry," Procedia - Soc. Behav. Sci., vol. 224, pp. 149-157, Jun. 2016, doi: 10.1016/j.sbspro.2016.05.430.

[24] T. Kaurin and A. Bošković, "Customer Satisfaction Assessment by Online Shopping Service: A Case Study of Serbia," Teh. Vjesn., vol. 27, no. 5, pp. 1631$1637,2020$. 